\title{
MSW management for waste minimization in Taiwan: The last two decades
}

\author{
Li-Teh Lu ${ }^{\text {a,* }}$, Teng-Yuan Hsiao ${ }^{b}$, Neng-Chou Shang ${ }^{a}$, Yue-Hwa Yu ${ }^{a}$, Hwong-Wen Ma ${ }^{\text {a }}$ \\ ${ }^{a}$ Graduate Institute of Environmental Engineering, National Taiwan University, 71, Chou-Shan Road, 10660 Taipei, Taiwan \\ b Department of Tourism Industry, Jin-Wen Institute of Technology, 99, Ann-Chung Road, 231 Taipei County, Taiwan
}

Accepted 12 October 2005

Available online 7 December 2005

\begin{abstract}
Taiwan is the second most densely populated country in the world; its 22.604 million residents (2002) live in an area of $35,967 \mathrm{~km}^{2}$ (628 people $/ \mathrm{km}^{2}$ ). Taiwan's economy has grown rapidly during the last 20 years, resulting in a corresponding increase in the amount of municipal solid waste (MSW). This study describes and evaluates the municipal solid waste management system in Taiwan. The study's results indicate that the amount of MSW began to decline after 1997, when the government enforced aggressive MSW management policies. By 2002, total MSW production had dropped by $27 \%$, and the average daily per capita weight of MSW had fallen from $1.14 \mathrm{~kg}$ in 1997 to $0.81 \mathrm{~kg}$ in 2002. Summarizing the successful experience of MSW reduction in Taiwan, the most important factor was the government's combining of the MSW collection system with reduction/recycling programs. The second most important factor was the policy of extended producer responsibility, which laid a foundation of recycling by producers and retailers and promoted public recycling.
\end{abstract}

(C) 2005 Elsevier Ltd. All rights reserved.

\section{Introduction}

Municipal solid waste (MSW) management is a global problem. Discovering how to utilize waste reduction and resource recycling programs effectively has become a priority in recent years (Annegrete, 2001). The increasing production of MSW has reached the point at which changes must be made, including the implementation of waste minimization programs (Agapitidis and Frantzis, 1998). MSW minimization has been placed at the top of the solid waste management hierarchy (Bai and Sutanto, 2002). MSW

Abbreviations: C\&C, control and command; DSD, duales system Deutschland; EPR, extended producer responsibility; GNP, gross national product; LCIA, life cycle inventory assessment; MSW, municipal solid waste; OECD, organization for economic cooperation and development $\mathrm{PE}$, polyester; PET, polyethylene terephthalate; PP, polypropylene; PS, polystyrene; PVC, polyvinyl chloride; VCF, volume-based collection fee.

Corresponding author. Tel.: +886 918135732; fax: +886 223067783.

E-mail address: luliteh@ms13.hinet.net (L.-T. Lu). minimization consists of two basic operations: sources reduction and recycling (Hopper et al., 1993).

To assess MSW management systems, a simple indicator to simulate the effects of MSW management systems across different regions was adopted. Assessment of an optimal waste disposal system should utilize a number of standard indicators (Hasome et al., 2001). Wilson (2002) evaluated the strategies, systems, operations, and economic factors of MSW management systems in other countries. Wilson adopted the life cycle inventory assessment (LCIA) to compare environmental loadings for different regulations proposed for MSW management. China's waste disposal issues include soil, air, and water pollution; mixed-waste collection; improper management; inadequate equipment and training, and the public's lack of understanding of the disposal system (Wang, 2001a). The effect of these unresolved issues is that nearly half of China's waste is being dumped on the outskirts of cities, resulting in substantial environmental pollution (Wang, 2001b). In addition, a description and analysis of MSW management in Taiwan 


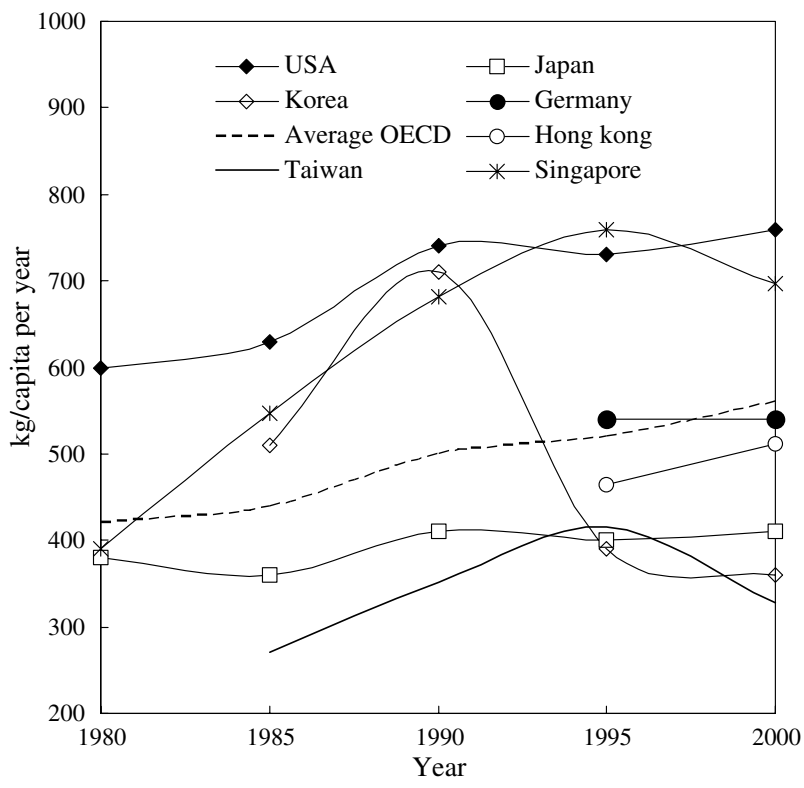

Fig. 1. Comparison of MSW generation in some countries from 1980 to 2000 (OECD, 2002). was needed and few studies focused on this issue. This paper analyzes MSW management in Taiwan during the last two decades, evaluates the policy of waste minimization, and identifies future challenges.

\section{Comparison of MSW management policy between Taiwan and other countries}

Reviewing the amounts of MSW produced in organization for economic cooperation and development (OECD) countries reveals that the amount of waste generated per capita per day in Taiwan was below $1 \mathrm{~kg}$ in 2000, while in all other OECD countries the amount exceeded $1 \mathrm{~kg}$. In Asia, between Singapore, Hong Kong, South Korea, and Taiwan, Taiwan was also the lowest (OECD, 2002). Fig. 1, compares MSW production in selected countries from 1980 to 2000 (OECD, 2002). The results show that other countries have also experienced a major and rapid increase in waste production over the last 20 years. In addition, Taiwan's accomplishments in reducing MSW are remarkable when compared to other countries.

Table 1

Comparison of the MSW composition in Taiwan and other countries in 2000 (OECD, 2002; TEPA, 2003)

\begin{tabular}{lllllll}
\hline & Paper $(\%)$ & Food and garden waste $(\%)$ & Plastics $(\%)$ & Glass $(\%)$ & Metals $(\%)$ & Textiles and others $(\%)$ \\
\hline USA & 38 & 23 & 11 & 5 & 8 & 15 \\
Japan & 33 & 34 & 13 & 5 & 3 & 12 \\
Korea & 26 & 25 & 7 & 6 & 3 & 29 \\
Netherlands & 28 & 39 & 5 & 3 & 3 & 19 \\
Hong Kong & 27 & 33 & 17 & 1 & 3 & 18 \\
Singapore & 21 & 50 & 22 & 7 & 4 & 9 \\
Taiwan & 26 & 31 & & 6 & & 9 \\
\hline
\end{tabular}

Table 2

Comparison of the recycling systems of Germany, Japan and Taiwan (Chen, 2003)

\begin{tabular}{llll}
\hline & Germany & Japan & Taiwan \\
\hline $\begin{array}{l}\text { Recycling laws } \\
\text { Recyclable items }\end{array}$ & $\begin{array}{l}\text { Recycle and Waste Material Control Act } \\
\text { Containers, appliances, vehicles, } \\
\text { lubricants, batteries }\end{array}$ & $\begin{array}{l}\text { Bill of resources recycling } \\
\text { Containers/packages, household } \\
\text { electrical appliances, vehicles }\end{array}$ & $\begin{array}{l}\text { Waste Disposal Act } \\
\text { Containers, batteries, motorcycles/ } \\
\text { automobiles, batteries, tires, } \\
\text { lubricants, electrical appliances, } \\
\text { computer products, etc. }\end{array}$ \\
& &
\end{tabular}

Structure

Organization

Participation

Implementation

Payment methods

Subsidy methods

Auditing/certification methods
- Private business operates on volunteer basis (Duales System Deutshland, DSD)

- Manufacturers

Volunteer

Green Dot organization and manufacturers

Pay the Green Dot fee to DSD

DSD pays to the recycling contractors

By the neutral third parties; once or several times annually
- Government appointed private business (JCPRA)

- Manufacturers with permits

\section{Drafted}

Collected by garbage pick-up first and then handed over to recycling contractors for further processing

Pay to government, according to the published rates

Government pays the amount, and it was determined by open bid

By the JCPRA
Recycling Fund Management Board

Drafted mandatory

Government waste collection crews, communities, school, and recycling industry

Pay to the management board, according to EPA-designated rates Management board pays it, according to the designated rates

By the neutral third parties; throughout the year 
Table 3

Comparison of recycling tonnages, ratios, and fees for various recyclable materials in Germany, Japan and Taiwan in 2002 (Chen, 2003)

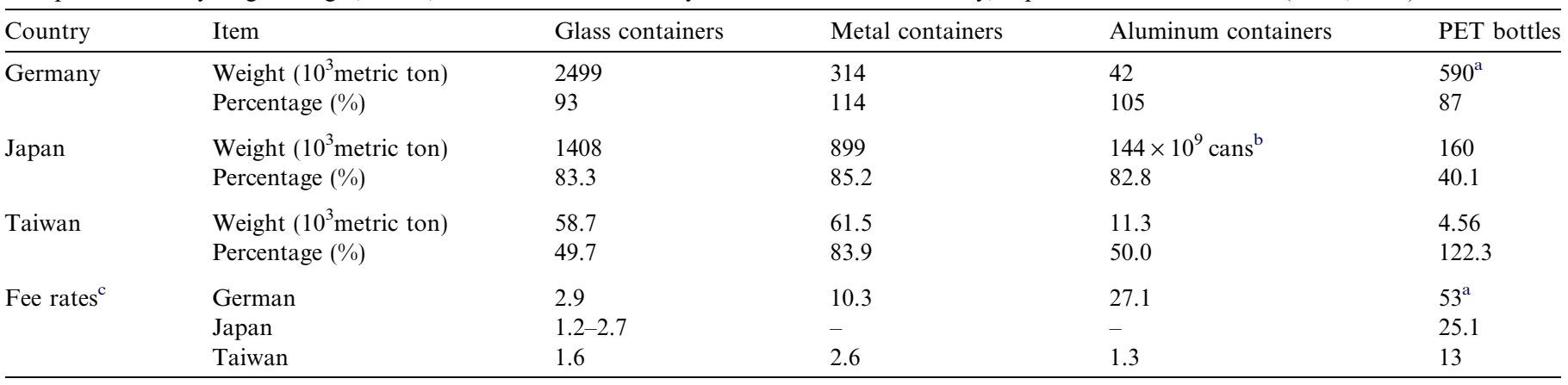

${ }^{\text {a }}$ Statistic on PET bottles in fact is statistic of plastic in total.

b The aluminum cans were accounted by quantity, not by weight.

${ }^{\mathrm{c}}$ Unit: NT $\$ / \mathrm{kg}$ (US $\$ 1=$ NT $\left.\$ 32\right)$.

The composition of MSW in Taiwan is shown in Table 1 (OECD, 2002; TEPA, 2003). Food and garden waste comprises the highest portion, followed by paper and plastics. Table 1 also compares the composition of MSW in Taiwan with the compositions in other countries. This comparison indicates that the contribution of plastics in Taiwan is considerably higher than in other countries, almost double the percentage in Japan and the US.

Japan and Germany are the two most aggressive nations in the world when it comes to the promotion of recycling and waste reduction. Taiwan followed Germany's Duales System Deutschland (DSD) recycling system (Vehlow, 1996) and started its own recycling program in 1989. A comparison of recycling systems in Japan, Germany, and Taiwan is shown in Table 2. The results of these systems are compared in Table 3 (Chen, 2003).

\section{Review and discussion of MSW management in Taiwan}

Taiwan is small and densely populated, with over 22 million people inhabiting a total area of less than $36,000 \mathrm{~km}^{2}$. The average population density was 628 peo$\mathrm{ple} / \mathrm{km}^{2}$ in 2002. The waste-collection crews who collect and transport waste in Taiwan are employed by local government agencies. These crews were comprised of a total of 19,082 waste-collection employees with 4889 garbage trucks in 2002 (TCEPD, 2002). Since the 1980s, the economy has grown dramatically and per capita income levels have risen in Taiwan. Therefore, the amount of MSW generated has climbed considerably. The average daily production of MSW per capita in Taiwan increased from $0.63 \mathrm{~kg}$ in 1981 to $1.14 \mathrm{~kg}$ in 1997 . The average annual growth rate in the amount of MSW is over $4.78 \%$ (TDGBAS, 2001).

\subsection{Stages of MSW management}

During the last two decades in Taiwan, MSW management could be separated into three stages; a description of these stages is given in Table 4. Generally speaking, there were no policies on MSW reduction from 1981 to 1989 in Taiwan (Stage 1 of MSW management). The initial MSW recycling policy was begun in 1990 . However, the daily per capita production of MSW still increased rapidly from 1990 to 1997 (Stage 2, the first-period of MSW recycling). The MSW decreased significantly from 1997 to 2002 during the second-period of MSW recycling (Stage 3). Taiwan had faced the problem of rapid increase in MSW during the previous 20 years.

The initial work on MSW recycling and reduction was started by adopting recycling systems from developed countries, namely by extending and legislating the respon-

Table 4

Three stages of MSW management in Taiwan

\begin{tabular}{ll}
\hline Stages & Description \\
\hline 1981-1989 (Stage 1) & $\begin{array}{l}\text { The waste reduction and resource recycling were not considered in the strategy of MSW management. } \\
\text { Annual MSW grew at an average rate of 4.7\% during this stage. } \\
\text { 1990-1997 (Stage 2, first-period } \\
\text { of MSW recycling) }\end{array}$ \\
$\begin{array}{l}\text { The Taiwan Environmental Protection Administration (TEPA) announced the requirement that manufacturers } \\
\text { and retailers should be responsible for recycling the materials including the PET bottles, steel cans, } \\
\text { aluminum cans,PS, PVC, PE, PP, aseptic packaging, glass containers, paper containers, scrap tires, } \\
\text { spent mercury cell batteries, waste agricultural chemical containers, spent lead-acid batteries, waste lubricant oil }\end{array}$ \\
$\begin{array}{l}\text { and scrap motor vehicles (Lee et al., 2000). } \\
\text { The recycling organizations were established by manufacturers and importers, and which must pay the recycling } \\
\text { fees into a recycling fund that would be managed by the government. (Lee et al., 1998). In addition, the MSW } \\
\text { of MSW recycling) } \\
\text { collection system and reduction/recycling programs were combined by the government. The average daily per } \\
\text { capita weight of MSW was reduced from 1.14 kg in } 1997 \text { to 0.81 kg in 2002 during this stage. }\end{array}$ \\
\hline
\end{tabular}


Table 5

Comparing the first and second-periods of recycling in Taiwan (TEPA, 2003)

\begin{tabular}{|c|c|c|}
\hline Period & First-period: management by manufactures and importers & $\begin{array}{l}\text { Second-period: TEPA Recycling Fund Management } \\
\text { Board }\end{array}$ \\
\hline Duration & 1989-1997 & 1997 to date \\
\hline Control & $\begin{array}{l}\text { Government indicated the scope of responsibility, } \\
\text { recyclable items, recycling procedures and annual recycling } \\
\text { quota }\end{array}$ & $\begin{array}{l}\text { Government designated businesses to pay the recycling fee, } \\
\text { which was managed by the Recycling Fund Management } \\
\text { Board }\end{array}$ \\
\hline Auditing and certification & Auditing by recycling organization; supervised by TEPA & Third-party auditor appointed by TEPA \\
\hline Recycling fee rates & Determined by each respective recycling organization & $\begin{array}{l}\text { Determined by EPA, the fee was based on the material, } \\
\text { volume, weight and recycling values }\end{array}$ \\
\hline
\end{tabular}

sibility of manufacturers (the extended producer responsibility program, or EPR) (see Table 4).

In the second recycling period, the important changes involved a modification of the EPR system of first-period MSW recycling. Specifically, manufacturers were no longer directly involved in recycling. They were required to pay disposal fees whose rates were set by the Taiwan Environmental Protection Administration (TEPA). The TEPA combined the recycling organizations, which had originally been established by manufacturers and importers. Therefore, the government became directly involved in recycling management. Table 5 presents a comparison of the first and second stages of recycling.

\subsection{Trends in $M S W$ generation}

Statistics on MSW collected over the last 5 years reveal that the daily per capita production of MSW fell from $1.14 \mathrm{~kg}$ in 1997 to $0.81 \mathrm{~kg}$ in 2002, an almost 30\% reduction in the daily production of MSW (Fig. 2).

Theoretically, based on the average 3\% rate of increase in MSW during the second stage of MSW (first-period of recycling), the production of MSW should have reached $1.33 \mathrm{~kg} / \mathrm{capita} /$ day by 2002 in Taiwan. However, the daily

\footnotetext{
$\longrightarrow$ Per Capita GNP (U.S.\$)

$\checkmark$ Budget of Solid Waste Management (million N.T.\$)

. - . Amount of Refuse Collected and Transported (Kg / Per Capita Per Day)
}

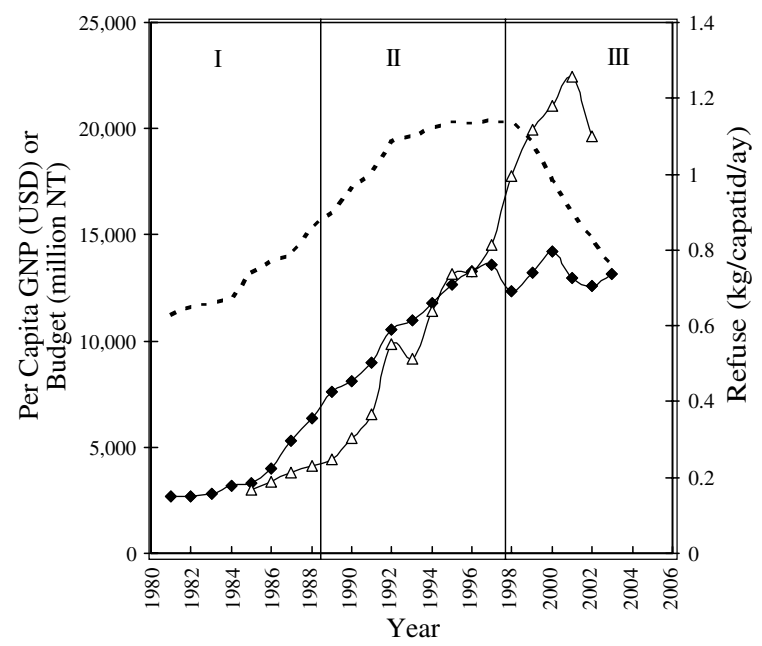

Fig. 2. Statistics on MSW generation and financial indicators from 1981 to 2002 in Taiwan (TDGBAS, 2002; TCEPD, 2002). per capita production of MSW was actually $0.81 \mathrm{~kg} / \mathrm{capita} /$ day in 2002. Therefore, the MSW reduction was $0.50 \mathrm{~kg} /$ capita/day and the reduction rate of MSW was $37 \%$. In addition, Fig. 2 shows a general correlation between the budget for MSW and the GNP from 1985 to 1997. The correlation between average per capita GNP and amount of refuse collected and transported over the three stages of MSW in Taiwan is shown in Fig. 3. The results reveal that there is high positive correlation in Stages 1 and 2, but not in Stage 3. The orientation of MSW growth was converted in 1997 and MSW could be effectively reduced and controlled during the second-period of recycling.

The budget for MSW continued to grow after 1997 even though Taiwan's GNP slowed. The key point of this dramatic change is the recycling fee collected from manufacturers: with the recycling fund, the government became able to undertake waste reduction and recycling activities. Before 1997, Taiwan's government lacked sufficient funds to perform the required waste reduction and recycling activities and was only able to provide for the collection, transportation, and treatment of MSW. However, after 1997 policies changed: although the growth of GNP slowed, the budget for MSW collection increased by $2-3$ billion NT dollars (US $\$ 1=$ NT $\$ 32$ ) every year. Taiwan's government started performing waste recycling and reduction work, resulting in a decrease in the amount of MSW. We can therefore infer that because

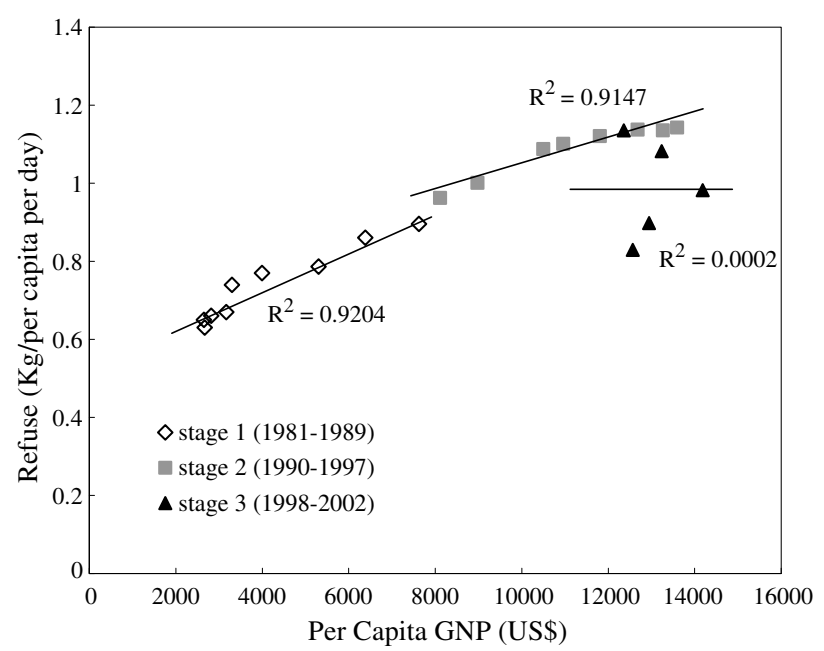

Fig. 3. Correlation between GNP and amount of refuse collected and transported for three stages of MSW in Taiwan. 
of the waste reduction policy that began in 1998, the MSW budget increased and the amount of MSW decreased, in spite of the fact that GNP growth slowed. Increased budgets and a decreasing amount of MSW attest to the government's dedication to improving recycling during this period.

The reasons why the policy of MSW reduction was successful can be listed as follows:

1. Mandatory waste recycling by law (described in next section).

2. Mandatory participation of local government waste collection crews in recycling (described in next section).

3. Citizens began placing their waste directly into garbage trucks. The trucks stop at designated points at designated times, allowing the public to throw waste directly into the trucks. It was this new method that facilitated the simultaneous collection of recyclable waste and general waste. Moreover, citizens could reduce waste on their own. This system first operated in Taipei in 1996, and was adopted in the rest of the country by 1998.

\subsection{Mandatory waste recycling by law}

The local government issued official announcements to follow mandatory waste recycling according to the Waste Disposal Act. The Act required the public to take its recyclable waste to waste-collection crews or scrap processors. In accordance with Article 23, Paragraph 2 of the Waste Disposal Act, people who threw out recyclable waste with general waste would be fined NT \$1200-6000 (US \$1 = NT $\$ 32$ ), and the waste-collection crews could also refuse to accept these mixed wastes.

The TEPA once more revised the mandatory recycling system of the Waste Disposal Act. New amendments made it mandatory for waste-collection crews to recycle 12 general waste items. The waste-collection crews were required to sort these recyclable items and were prohibited from disposing these items with general waste (see next section). The earnings from recycling were then used to reward the organization groups, communities, and collection crews which promoted the recycling program. The principle of rewards and punishment was to encourage the public to participate in the implementation of the MSW sorting and recycling activities.

\subsection{Mandatory participation of local government waste-collection crews in recycling}

Since, the waste-collection crews of the local government were responsible for the collection, transportation, and recycling of Taiwan's MSW, the TEPA used its recycling fund to subsidize the recycling work. The TEPA purchased the recycling trucks that the local governments used. These trucks accompanied the garbage trucks so that the recyclable waste could be collected at the same time. The number of recycling trucks operated by the local government waste-collection crews was 2050 in 2002. The local governments had set up 263 storage sites for recyclable waste. Each local government dispatched the crews to pick up the recyclable waste twice a week. The amount of recyclable waste collected by the waste-collection crews of local government was 584,330 tons in 2001 , which amounted to more than $55 \%$ of the total recycling amount (see Table 6).

\subsection{The evaluation of management policy in different stages of $M S W$}

The environmental management tools during the various stages of MSW in Taiwan are summarized in Table 7. Numerous environmental management strategies have been instituted in Taiwan. The waste reduction and recycling management work has relied on them. In chronological order, the management strategies were environmental education, EPR, control and command $(\mathrm{C} \& \mathrm{C})$, and the use of economic incentives to achieve its goal of MSW reduction. A detailed description follows:

1. The setting up of numerous recycling sites and the promotion of the concept of recycling to the public (environmental education).

2. Restrictions on the use of disposable dishes, and encouragement of the public to develop the habit of "waste not, want not" to promote waste reduction and recycling (environmental education).

3. Collecting recycling fees from businesses and applying them to call attention to recycling work (EPR).

4. Mandating that waste-collection crews of the local government perform waste recycling and reduction work $(\mathrm{C} \& \mathrm{C})$.

5. Mandating public participation in recycling and refusing to collect waste from those who do not cooperate in sorting and recycling $(\mathrm{C} \& \mathrm{C})$.

Table 6

Waste reduction and recycling in Taiwan (TEPA, 2003)

\begin{tabular}{|c|c|c|c|c|c|c|c|}
\hline Year & 1996 & 1997 & 1998 & 1999 & 2000 & 2001 & 2002 \\
\hline Total recycling (tons) & - & - & 426,793 & 637,351 & 855,675 & $1,055,055$ & - \\
\hline Recycling by local government waste-collection crews (tons) & - & 106,201 & 129,155 & 215,864 & 477,856 & 584,330 & - \\
\hline Total recycling rate $(\%)$ & - & - & 4.59 & 6.88 & 9.78 & 12.72 & 15.50 \\
\hline Recycling rate by local government waste-collection crews (\%) & - & - & 1.25 & 1.94 & 5.75 & 7.47 & - \\
\hline Total MSW quantity (tons) & - & $8,880,779$ & $8,880,487$ & $8,565,700$ & $7,880,637$ & $7,258,236$ & $6,764,968$ \\
\hline Daily per capita MSW (kg) & 1.135 & 1.143 & 1.135 & 1.082 & 0.977 & 0.893 & 0.806 \\
\hline
\end{tabular}


Table 7

Summarizing the environmental management tools during the various stages of MSW management in Taiwan

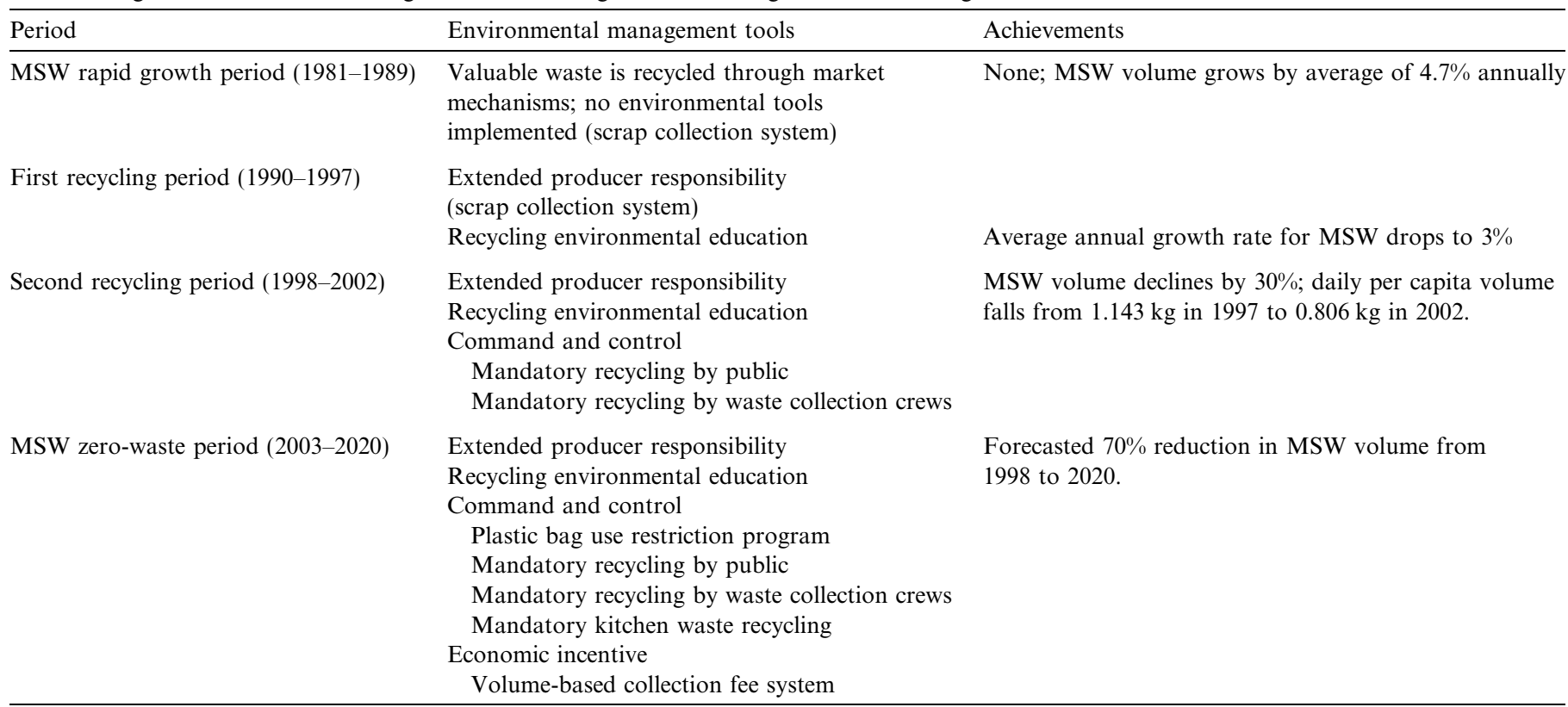

6. Setting up restrictions on the use of plastic bags (C\&C).

7. Implementation of kitchen-waste recycling $(C \& C)$.

8. Introduction of a volume-based collection fee system (economic incentive).

\subsection{Volume-based collection fee (VCF) system, begun in Taipei City in July 2000}

The volume-based collection fee (VCF) system began operating in Taipei City in July 2000. This system mandated that waste-collection fees be paid by citizens. These fees represent a polluter-pay system. In the past, Taipei City assessed waste-collection fees based on household water usage at a rate of NT $\$ 4$ (US $\$ 1=\mathrm{NT} \$ 32$ ) for each ton of water used. Although this system was convenient, because of the indirect relationship between waste production and water usage, it was not particularly fair. Moreover, the fee was not reduced for those who reduced their waste, so individual citizens could not benefit directly by reducing the amount of waste they generated. To eliminate this shortcoming, the Taipei City government introduced a VCF system and discontinued the water-fee-based system on July 1, 2000. Under the VCF system, citizens purchase an Environmental Protection Bureau-authorized garbage bag for the disposal of general waste. These bags are easily purchased at stores throughout the city. Penalties for those who manufacture pirated waste bags include possible prison sentences. Citizens benefit directly by reducing waste and recycling. Recyclable waste is separated from general waste while general waste is disposed of in the designated waste bags. The price of $1 \mathrm{~kg}$ pay-by-bag (mass-based) currently is NT $\$ 0.45$ (US $\$ 1=$ NT $\$ 32$ ) in Taipei City's VCF system.
The VCF system reduced the average daily MSW amount from the 3695 tons in 1999 to 2649 tons in 2002, resulting in a waste reduction rate of $28.3 \%$ and an increase in the recycling rate from $2.3 \%$ to $23.0 \%$.

\section{The way forward}

Taiwan's government has continued to set new policies regarding MSW management. These include imposing fees for MSW collection and treatment after 2000, limiting the use of plastic bags, and implementing kitchen-waste recycling programs. The official plan is to achieve the goal of "zero MSW" by 2020. There are still a great many challenges in the future of MSW treatment in Taiwan, as specified below.

\subsection{Plastic bag use restriction program (Begun in 2003)}

As a means of promoting simpler living and gradually altering the throw-away consumer habits of the public, Taiwan chose to try and reduce the use of plastic shopping bags and disposable dishes. A sustainable-resource perspective prefers waste reduction where waste is produced.

The plastic bag restriction program has been implemented pursuant to the "use restriction" clause of Article 21 of the Waste Disposal Act. This program restricts the use of plastic shopping bags and plastic disposable dishes over a number of stages. It relies primarily on incentives and secondarily on subsidies to encourage businesses to introduce reusable shopping bags and dishes.

The program's target is to reduce the amount of plastic bags produced and consumed by 20,000 tons annually, a current usage-rate reduction of approximately $31 \%$, and to reduce the amount of plastic (including polystyrene) dis- 
posable dishes produced and consumed by 12,000 tons annually, a reduction in current usage rates of roughly $28 \%$.

\subsection{Food and garden waste recycling}

Statistics for 2002 show that of the average 18,421 tons of MSW collected daily in Taiwan, food and garden waste comprises roughly $25 \%$, or approximately 4500 tons. A trial food- and garden-waste recycling program was started in 2000. With 24 counties and cities, and 100 townships participating in this program, by the end of 2003 the amount of food and garden waste collected daily had already reached 300 tons (accounting for $6.7 \%$ of the recycling tonnage). Reuse of this waste includes pig feed (accounting for $68 \%$ of collected food waste) and composting (accounting for $32 \%$ ). This food-waste recycling program is expected to be implemented throughout all of Taiwan by 2004 and the amount of food and garden waste recycled is forecast to account for $17 \%$ of the total waste tonnage collected by 2020 .

\subsection{The goal of zero waste for $M S W$}

As resources have become scarcer and MSW disposal costs have continued to climb, Taiwan has gradually turned to source reduction and recycling to replace its former "end-of-pipe" waste disposal methods. At present Taiwan is aggressively formulating waste reduction and recycling/reuse programs to achieve its goal of establishing a zero-waste society.

Zero waste for MSW means no more landfills for final disposal of raw MSW but rather utilizing methods of source reduction and resource recycling. In 1998, MSW collected in Taiwan reached 8.88 million tons, while recyclable waste collected was 0.55 million tons, a total of 9.43 million tons. Taking these 1998 figures as its starting point, Taiwan aims to reduce the total amount of raw MSW by $25 \%$ by $2007,40 \%$ by 2011 , and $70 \%$ by 2020 . Ways of achieving this goal are related to recycling and reuse programs.

\section{Conclusion}

The following conclusions can be drawn from the foregoing analysis. Taiwan experienced a rapid growth in GNP and a steady increase in MSW production beginning in 1982. Prior to 1989 Taiwan's MSW management strategy focused on waste disposal. However, this was ineffective in restraining the marked growth rate of waste produced. In 1989, Taiwan began to promote MSW recy- cling with an emphasis on avoidance and reduction. As a result of effective management, the growth of waste production was controlled.

The mandatory participation of the public in waste recycling was an important factor in Taiwan. We have seen successful results of the waste reduction system after the MSW collection system was combined with the recycling system by the government during the second-period of recycling (1998-2002).

\section{References}

Agapitidis, I., Frantzis, I., 1998. A possible strategy for municipal solid waste management in Greece. Waste Management and Research 16 (3), 244-252.

Annegrete, B., 2001. Factors influencing solid waste generation and management. Journal of Solid Waste Technology and Management 27 (3/4), 156-162.

Bai, R., Sutanto, M., 2002. The practice and challenges of solid waste management in Singapore. Waste Management 22, 557-567.

Chen, H.-W., 2003. Current Status and Future Prospects of Resource Recycling in Taiwan, Proceedings of the 7th International Symposium on East Asia Resources Recycling Technology, pp. 17-22.

Hasome, H., Tachio, K., Yokota, I., Nitta, Y., 2001. Studies on the evaluation of municipal waste management systems. Waste Management and Research 19, 2-11.

Hopper, J.R., Yaws, C.L., Ho, T.C., Vickhailak, M., 1993. Waste minimization by process modification. Waste Management 13 (3).

Lee, C.-H., Chang, C.-T., Tsai, S.-L., 1998. Development and implementation of producer responsibility recycling system. Resources, Conservation and Recycling 24, 121-135.

Lee, C.-H., Chang, S.-L., Wang, K.-M., Wen, L.-C., 2000. Management of scrap computer recycling in Taiwan. Journal of Hazardous Materials A 73, 209-220.

Organization for Economic Co-operation and Development (OECD), 2002. Environment Data: Compendium 2002. Available from: $<$ http:// www.oecd.org $>$.

TCEPD (The Taiwan Council for Economic Planning and Development), 2002. Compilation of Urban and Regional Development Statistics (in Chinese). Available from: $\langle$ http://www.cepd.gov.tw $>$.

TDGBAS (The Taiwan Directorate General of Budget, Accounting and Statistics), 2001. ROC Social Indicator Statistics (in Chinese), p. 12, pp. 110-111.

TDGBAS (The Taiwan Directorate General of Budget, Accounting and Statistics), 2002. ROC Social Indicator Statistics (in Chinese), p. 12, pp. $110-111$.

TEPA (The Taiwan Environmental Protection Administration), 2003. Working Plan for the Assessment and Evaluation of Waste Disposal Policies (in Chinese). EPA-91-H101-02-207.

Vehlow, J., 1996. Municipal solid waste management in Germany. Waste Management 16 (5/6), 367-374.

Wang, H., 2001a. Remedial strategies for municipal solid waste management in China. Journal of the Air and Waste Management Association, 264-272.

Wang, H., 2001b. Municipal solid waste characteristics and management in China. Journal of the Air and Waste Management Association, 250 263.

Wilson, E.J., 2002. Life cycle inventory for municipal solid waste management. Waste Management and Research 20, 16-22. 